\title{
THE SOCIAL DIMENSION AND INDICATORS OF SUSTAINABILITY IN AGRIFOOD SUPPLY CHAINS
}

Renato Rocha Dias Santos Universidade de Brazilia, Brazil

E-mail: renatoufv@bol.com.br

Patricia Guarnieri Universidade de Brasília, Brazil E-mail: patguarnieri@gmail.com

Otavio Moreira do Carmo Jr. Universidade de Brazilia, Brazil E-mail: otaviobahiano30@gmail.com

Silvia Araújo dos Reis Universidade de Brazilia, Brazil E-mail: silviaareis@yahoo.com.br

José Márcio Carvalho Universidade de Brazilia, Brazil E-mail: jmcarvalho1708@gmail.com

Carlos Rosano Peña Universidade de Brazilia,Brazil E-mail:gmcrosano@gmail.com

Submission: $10 / 31 / 2018$

Revision: 11/21/2018

Accept: 12/06/2018

\section{ABSTRACT}

Several organizations aim to establish and manage cooperative and collaborative actions in order to incorporate the principles related to sustainable management in supply chains. The indicators related to the social dimension are still barely explored in academic research, since the perceived business practices are still emerging in the contemporary world and in the organizational relations. The opposite of the financial and environmental dimensions, which are already rooted in the business environment. In agrifood chains, social aspects are essential when suppliers are often impoverished farmers, and labor practices are generally painful and exploitative. 
INDEPENDENT JOURNAL OF MANAGEMENT \& PRODUCTION (IJM\&P)

http://Www.ijmp.jor.br

V. 10, n. 5, September-October 2019

ISSN: 2236-269X

DOI: 10.14807/ijmp.v10i5.894

This paper aims to identify, in the international literature, the state-of-the-art research related to social sustainability in agrifood supply chains. To achieve this goal, a systematic literature review covering papers published in the Science Direct, Directory of Open Access Journals and Emerald Insight databases was carried out. Results indicate that academic production is still low, despite its growth in recent years, and is limited to approaches containing indicators of social sustainability related to support communities affected by agrifood business. In addition, it evidences arrangements among members of supply chains, mostly of the cooperative type, having collaborative arrangements with more limited approaches among the analyzed works.

Keywords: Agrifood supply chains, Sustainable Supply Chain Management, Social Indicators, Sustainability

\section{INTRODUCTION}

The scientific production related to the social dimension of sustainability in agrifood supply chains has been growing among authors of several areas of academic knowledge, because it is a multidisciplinary theme that involves several actions and practices along the supply chain. As pointed out by Hall and Matos (2010), the fight against social exclusion through the insertion of impoverished communities into sustainable supply chains has been debated by scholars and it is growing.

In order to achieve sustainability in supply chains, the process should not be confined to just one organization, but consider the various actors involved and extrapolate issues that go beyond the environmental ones. The concerns with the social issues in effect, preserving the conditions of the workers in supplier companies and forming collective partnerships for social development as a whole should be considered (JENKINS, 2001; PAGELL; WU, 2009; GUARNIERI; TROJAN, 2019).

Thus, the companies are subsidizing efforts to search for mutual gains in the supply chain by adding value to social inclusion in order to gain new markets through innovative mechanisms and a balance of power in the relations.

Distinguishing and identifying what actions and practices related to social sustainability is a challenge, since many academic works end up encompassing several research fields jointly, not delimiting the boundaries between the dimensions of financial, social or environmental sustainability. Therefore, this hinders an in-depth 
DOI: 10.14807/ijmp.v10i5.894

analysis of the characteristics and application fields of social issues in a Sustainable Supply Chain Management.

So, summarizing indicators of social sustainability can expose the most studied characteristics in the academic environment, verifying the most explored areas and research gaps in still incipient investigation fields, is fundamental, since it can trace characteristic elements of social sustainability present in publications, guide potential themes in researches and disseminate practices and experiences to the business community. Some indicators of social sustainability proposed by Labuschagne and Brent (2005) provide a categorization structure containing social indicators observed in sustainable supply chains, which are subdivided into four spheres of action: internal human resources, external population, stakeholder participation and macro-social performance.

Assuming that collective actions among members are essential to the management of sustainable supply chains with a view to achieving social gains and mutual benefits, it is elementary to expect that cooperative or more complex practices, such as collaborative practices, are present in the relations between the members that make up the supply chains and their related partners. Identifying these arrangements aims to consolidate the understanding of these concepts in relation to the social sustainability practices used and illustrates the academic approach taken by the researchers regarding cooperation and collaboration to improve social issues.

In agrifood chains, implementing a sustainable management is complex, since it encompasses a great variety of specificities that compose this type of relationship and entails different social aspects when it comes to raw material suppliers, especially when they are small impoverished rural producers, besides that the social issues are still few studied (GUARNIERI; TROJAN, 2019).

Maloni and Brown (2006) highlight that these supply chains are complex because they involve sensitive elements external to the business and, also require labor-intensive applications at all stages of the chain.

In order to obtain subsidies for studies related to social sustainability in agrifood supply chains and existing collective arrangements, the objective of this paper is to identify in the literature the state-of-the-art research that operates under the social sustainability dimension, identifying related indicators and vital cooperative or 
INDEPENDENT JOURNAL OF MANAGEMENT \& PRODUCTION (IJM\&P)

http://Www.ijmp.jor.br

V. 10, n. 5, September-October 2019

ISSN: 2236-269X

DOI: 10.14807/ijmp.v10i5.894

collaborative practices. For this purpose, it was carried out a descriptive, exploratory and qualitative research through the systematic literature review technique. The systematic review was based on the Cronin, Ryan and Coughlan (2008) protocol, through database searches on the Science Direct, Directory of Open Access Journals and Emerald Insight websites, using descriptors related to social sustainability in agrifood chains.

The result of the research indicates that the academic production of research related to social sustainability in the agrifood supply chain is still scarce, although it has shown a significant growth in recent years. Among the indicators of social sustainability that are less present in publications, macro-social issues related to regional or national impacts were the least considered by the authors. This paper demonstrates that the collaborative arrangements related to infrastructure sharing and the integration of productive processes among the agrifood supply chain are also few studied. The results also demonstrate that collective actions are more exploited when related to cooperation than collaborative arrangements.

\section{THEORETICAL BACKGROUND}

\subsection{Sustainable supply chain management}

The formulations of supply chain management related concepts are outlined in the late 1980s and early 1990s, leveraged by business consultants, and were object of attention by researchers and academics (LAMBERT; COOPER; PAGH, 1998). Regarding sustainable management in a supply chain, Srivastava (2007) points out that it is compartmentalized in different approaches, and a systemic view on the subject is necessary.

As part of a systemic view inherent in sustainable management, Carter and Rogers (2008, p. 368) defined sustainable supply chain management as: "strategic, transparent and consecutive integration of the social, environmental and financial objectives of an organization in the systemic coordination of the main interorganizational processes to improve the long-term financial performance of the individual company and its supply chains."

The emergence of these new relationships that underpin sustainable management emerges from the new organizational needs among the entities of the supply chain, which stems from a greater need to optimize productive and energy 
resources for cost reduction and value generation (KLEINDORFER; SINGHAL; VAN WASSENHOVE, 2005). However, Pagell and Wu (2009) point out that actions related to the environmental dimension excel in organizational practices, as they relate and reflect in financial aspects. In this context the financial aspects drive to the improvements in the efficiency of resource, which are prerequisite for competitiveness and, the social aspects have a secondary role.

A new order is given to organizations and academics, where waste reduction, quality, optimization of natural resources and processes with social benefits become essential elements for better practices (SRIVASTAVA, 2007). According to Green, Morton, and New (1998), the concept has established itself as a factor that provides financial gains.

Considering the new elements that integrate a SSCM, Pagell and Wu (2009) establish that the integration and new behaviors are part of this new conception of supply chain. Integration should involve aspects of quality, management, common objectives, values and fulfillment of commitments. New behaviors are projected on the participation of external actors in the supply chain in forming networks, transparency, traceability, certifications and differentiation of products, processes and services.

In relation to the elements that can configure a sustainable supply chain, Carter and Rogers (2008), when evaluating the sustainability performance of an SSCM, cite the following dimensions of analysis: integrated strategy, collective risk management, organizational social aspects and transparency. Seuring, Sarkis and Muller (2008) emphasize the clear and impersonal communication and the development of suppliers in socio-environmental issues as elements to obtain sustainable products.

Elkington (1997) added that only with the balance between the financial, social and environmental issues, it would be possible to properly conceptualize sustainable development; any postulated and based organizational practices that are said to be sustainable must necessarily be based on the Triple Bottom Line (TBL).

\subsection{SOCIAL SUSTAINABILITY AND ITS INDICATORS}

The financial issue and, later, the actions aimed at the environmental dimension have emerged as the main pillars of corporate sustainability in organizations, whereas the social aspect is often ignored and with low application to business (HOLLIDAY et al., 2002, VISSER; SUNTER, 2002, GUARNIERI; TROJAN, 2019). 
INDEPENDENT JOURNAL OF MANAGEMENT \& PRODUCTION (IJM\&P)

http://Www.ijmp.jor.br

V. 10, n. 5, September-October 2019

ISSN: 2236-269X

DOI: 10.14807/ijmp.v10i5.894

It is often common that social factors are not included in analysis procedures for project feasibility, limited to the verification of compliance with the current legislation by the organizations, next to collaborators and employees (VIFELL; SONERYD, 2012). Elkington (1997) already warned that some militants, in favor of sustainable development, considered that ethical, social and cultural issues have no relation to sustainability, since sustainability is related to resource efficiency.

According to Sarkis, Helms and Hervani (2010), sustainable development is displayed with a conceptual approach when involve aspects related to the environmental dimension, placing social issues on the fringe in organizations.

However, Elkington (1997) emphasizes that the business world is part of society, and that the levels of trust that it holds are dependent on the levels of investment in human capital. Fukuyama (1995) already stressed that living in a society with ethical standards will allow strong cohesion in social relationships and business will cost less.

Thus, ethical and socially responsible behavior should not be limited to the behavior of an organization only, but to the supply chain to which it is embedded or may influence, as well as in the markets in which it participates (ELKINGTON, 1997).

With the conceptual evolution of social sustainability, some factors were placed as central to their perception and involved actions next to the impacted communities and others, emphasizing the administration of social and internal resources to organizations such as people management and skills training (FOLADORI, 2002; DYLLICK; HOCKERTS, 2002; AHMED; MCQUAID, 2005). Social indicators are more adequate ways of measuring the generation of wealth coupled with social and individual well-being than the conventional measures applied nowadays (ELKINGTON, 1997).

In systematizing the indicators of social sustainability, Labuschagne and Brent (2005) propose in a study to verify the social aspects in the sustainability of industrial processes, a categorization structure of social indicators observed in a given supply chain, which are subdivided into 4 spheres of action: (i) Internal Human Resources; (ii) External Population; (iii) Stakeholder Participation; and (iv) Macro-Social Performance. 
INDEPENDENT JOURNAL OF MANAGEMENT \& PRODUCTION (IJM\&P)

http://Www.ijmp.jor.br

V. 10, n. 5, September-October 2019

ISSN: 2236-269X

DOI: 10.14807/ijmp.v10i5.894

Internal Human Resources: These resources correspond to the management of internal people participating in organizations within a sustainable supply chain, focusing on collaborators, employees, outsourced workers, among others present in labor relations, and are subdivided into: (a) employment stability, which relate to job opportunities and compensation for service with greater complexity accompanied by a fair and equitable remuneration; (b) occupational health and safety, which includes safe and healthy work practices in actions such as the prevention of accidents and occupational diseases, gender, ethnicity and racial equality, as well as respect for human rights and compliance with national and international legislation; and (c) capacity development, which encompasses training practices for innovation and development of skills among workers and members of the supply chain (LABUSCHAGNE; BRENT; ERCK, 2005).

External Population: This dimension is focused on the impacts of the operations of a given organization or a supply chain in communities that may be impacted or influenced by a particular economic activity. It involves aspects that guarantee gains as the individual working skills of the population as health, psychological integrity, wellbeing levels, education, training and interpersonal skills, called (a) human capital. (b) Productive capital refers to collective aspects, such as infrastructures that guarantee the well-being of the individual; and the formation of networks of trust, cooperation and reciprocity between the enterprise and those affected, which can be measured by sensory stimuli (aesthetics, noise levels and odor). The third and final characteristic of this dimension is linked to community capital (c) which involves actions that guarantee the legitimacy and preservation of cultural assets; combat to social pathologies; social security, economic welfare and social cohesion (LABUSCHAGNE; BRENT; ERCK, 2005).

Stakeholder Participation: Stakeholder participation is measured by the organization's availability and willingness to provide information, fostering transparency to the supply chain and empowering stakeholders with regard to decision-making power and capacity to influence organizations (LABUSCHAGNE; BRENT; ERCK, 2005). This process reflects on improved cooperative actions and can radiate into a collaborative chain, and to a greater degree, the coordinative chain. Thus, this sphere is subdivided into two aspects, (a) information provision and (b) stakeholder influence. 
INDEPENDENT JOURNAL OF MANAGEMENT \& PRODUCTION (IJM\&P)

http://Www.ijmp.jor.br

V. 10, n. 5, September-October 2019

ISSN: 2236-269X

DOI: 10.14807/ijmp.v10i5.894

Macro-social Performance: This performance is linked to aspects where the organization can influence external populations in the supply chain regionally or nationally. They can be measured by indicators related to: (a) socio-economic performance, which may be, tax generation, GDP growth and currency consolidation; or by (b) socio-environmental performance, which measures the organization's potential to generate welfare to target communities and its monitoring, as well as legal procedures that help consolidate regulations with governments and society (LABUSCHAGNE; BRENT; ERCK, 2005).

\section{METHODS AND RESEARCH TECHNIQUES}

In order to guarantee adequate reliability and validity of the literature review, the author must specify the criteria used in the research, following the subsequent steps: (i) formulate the research question; (ii) define inclusion or exclusion criteria; (iii) select and access the literature; (iv) evaluate the quality of the literature included in the evaluation; ( $v$ ) analyze, synthesize and disseminate the results (CRONIN; RYAN; COUGHLAN, 2008). Thus, the criteria and filtering process used for this systematic literature review are presented:

Definition of the research question: What are and what is the approach of the current studies related to social sustainability indicators in the sustainable management of the agrifood supply chain, and what collective and integrative actions are identified?

Definition of the inclusion and exclusion criteria: The criteria are keywords associated with Boolean operators, scientific databases, publication period and types of articles. As the proposed study deals with a multidisciplinary theme, there may be periodicals in several areas of knowledge, such as: Administration, Production Engineering, Process Engineering, Sociology, Law, Environmental Engineering, Agronomy, among others. This article was delimited for scientific research: Science Direct, Directory of Open Access Journals and Emerald Insight.

The use of various collection databases aims to broaden the variety of studies and later, to use objective criteria for refinement and selection of the most representative ones. After choosing the scientific bases for research, we defined the period of publication that considered the last 10 years, covering from 2006 to 2016 . The keywords were defined for the search of factors that are part of the social 
INDEPENDENT JOURNAL OF MANAGEMENT \& PRODUCTION (IJM\&P)

http://Www.ijmp.jor.br

V. 10, n. 5, September-October 2019

ISSN: 2236-269X

DOI: 10.14807/ijmp.v10i5.894

dimension and were delimited under the book Cannibals with Forks by Elkington (1997), considering the combined descriptors, preserving, in all combinations, the term supply chain as the base axis for the search in the databases. The search combinations were: (a) supply chain, social development, food, (b) supply chain, social development, agriculture, (c) supply chain, social development, agrifood, (d) supply chain, social responsibility, food, (e) supply chain, social responsibility, agriculture, (f) supply chain, social responsibility, agrifood, (g) supply chain, social sustainability, food, (h) supply chain, social sustainability, agriculture, (i) supply chain, social sustainability, agrifood, (j) supply chain, social justice, food, (I) supply chain, social justice, agriculture, (m) supply chain, social justice, agrifood, (n) supply chain, social truth, food, (o) supply chain, social truth, agriculture, (p) supply chain, social truth, agrifood, (q) supply chain, ethic, food, (r) supply chain, ethic, agriculture, (s) supply chain, ethic, agrifood.

Regarding to the selected articles, it was defined that only articles published in periodicals would be considered, excluding those published in annals of events, patents, quotations and book chapters. The Boolean operator used was the AND, excluding the OR and NOT operators, since the results should reflect articles related to the social sustainability of agrifood supply chain.

Literature selection and access: Overall results using keyword combinations in the Science Direct, Directory of Open Access Journals and Emerald Insight databases totaled 63 publications. Considering the established exclusion criteria, 12 publications were excluded from this population, since they were related to events and book chapters, and 7 were repeated publications of articles already collected in the research bases when the combined descriptors were applied. Thus, 44 articles were selected for further analysis and verification for inclusion in the sample.

Evaluation of the literature quality included in the review: Considering the Science Direct database, 18 articles were selected applying the descriptors and the exclusion criteria, but only 10 were selected to compose the sample, since 8 were eliminated because the topics, after analysis of the summary and introduction of each publication, were not related to the proposed study and were excluded due to their content. At the Directory of Open Access Journals database, of the 10 studies selected after the first exclusion criteria, only 6 were selected for the sample and the others were excluded because they did not align to the proposed objective after analyzing the abstracts 
INDEPENDENT JOURNAL OF MANAGEMENT \& PRODUCTION (IJM\&P)

http://Www.ijmp.jor.br

V. 10, n. 5, September-October 2019

ISSN: 2236-269X

DOI: 10.14807/ijmp.v10i5.894

published in the portal. Finally, with respect to Emerald Insight, 16 articles were selected and 13 included in the sample, since these were aligned with the objectives proposed by this article. Considering the exclusion criteria applied, the sample that will compose the analysis totalize 29 articles.

Table 1 summarizes the quantitative of search returns, of publications deleted by exclusion criteria, and of articles excluded by content analysis; at the end, a detailing of the articles that will compose the sample of this literature review is presented.

Table 1: Quantitative selected for analysis

\begin{tabular}{ccccc}
\hline Types & $\begin{array}{c}\text { Return } \\
\text { Searches }\end{array}$ & $\begin{array}{c}\text { Exclusion of Book } \\
\text { Chapters, Article } \\
\text { Events and } \\
\text { Repetitions }\end{array}$ & $\begin{array}{c}\text { Exclusion by } \\
\text { Content } \\
\text { Analysis }\end{array}$ & $\begin{array}{c}\text { Total } \\
\text { Articles of } \\
\text { the Sample }\end{array}$ \\
\hline $\begin{array}{c}\text { Science Direct } \\
\text { Directory of } \\
\begin{array}{c}\text { Open Access } \\
\text { Journals }\end{array}\end{array}$ & 18 & 9 & 8 & 10 \\
$\begin{array}{c}\text { Emerald } \\
\text { Insight }\end{array}$ & 18 & 8 & 4 & 6 \\
Total & 63 & 2 & 3 & 13 \\
\hline
\end{tabular}

Analysis, synthesis and dissemination of results: This step demonstrates the analysis for each selected article considering the contents of the articles housed in the portals Science Direct, Directory of Open Access Journals and Emerald Insight. Thus, the data were tabulated in electronic spreadsheets and classified with the respective authors by: social sustainability indicators, classified according to the Labuschagne, Brent and Erck (2005) criteria; cooperative actions, identified according to the Britto (2002) and Brito (2001) classifications; collaborative actions and scope classifications, according to the dimensions of Barrat (2004); research design; collaborative relationships among members of the supply chain; predominant research design.

\section{PRESENTATION, ANALYSIS AND DISCUSSION OF DATA}

Indicators related to social sustainability were identified in the articles that compose the sample collected, considering the criteria established by Labuschagne, Brent and Erck (2005) and were classified according to the dimensions established by the same authors. It should be emphasized that indicators play a mutable and evolving role in response to the aspirations of society and the conceptual evolution of the understandings and can be developed in future moments as organizations actually 
INDEPENDENT JOURNAL OF MANAGEMENT \& PRODUCTION (IJM\&P)

http://Www.ijmp.jor.br

V. 10, n. 5, September-October 2019

ISSN: 2236-269X

DOI: 10.14807/ijmp.v10i5.894

evaluate their net contributions to the real generation of social wealth to the society (Elkington, 1997).

Table 2 presents the results of the indicators present in the articles analysed and correspond to each author of the publications. In it the classification of indicators identified in light of the analysis of the articles are placed, as well as the sphere of the indicators to which they belong.

Table 2: Social Sustainability Indicators in Agrifood Supply Chains

\begin{tabular}{|c|c|c|c|c|}
\hline AUTHORS & $\begin{array}{l}\text { INTERNAL HUMAN } \\
\text { RESOURCES }\end{array}$ & $\begin{array}{l}\text { EXTERNAL } \\
\text { POPULATION }\end{array}$ & $\begin{array}{l}\text { STAKEHOLDER } \\
\text { PARTICIPATION }\end{array}$ & $\begin{array}{l}\text { MACRO-SOCIAL } \\
\text { PERFORMANCE }\end{array}$ \\
\hline $\begin{array}{c}\text { Manning, Baines and } \\
\text { Chadd }(2006)\end{array}$ & $\begin{array}{l}\text { Health and Safety, } \\
\text { Employment Practices }\end{array}$ & Human Capital & $\begin{array}{l}\text { Information Provision, } \\
\text { Stakeholder Influence }\end{array}$ & \\
\hline $\begin{array}{l}\text { Rimmington, Cariton and } \\
\text { Hawkins (2006) }\end{array}$ & & Human Capital & $\begin{array}{l}\text { Information Provision, } \\
\text { Stakeholder Influence }\end{array}$ & $\begin{array}{c}\text { Financial } \\
\text { and Environmental } \\
\text { Performance }\end{array}$ \\
\hline $\begin{array}{l}\text { Fearne, Duffy and } \\
\text { Homibrook (2006) }\end{array}$ & & & $\begin{array}{l}\text { Information Provision, } \\
\text { Stakeholder Influence }\end{array}$ & \\
\hline Setthasakcko (2007) & Health and Safety & Human Capital & $\begin{array}{l}\text { Information Provision, } \\
\text { Stakeholder Influence }\end{array}$ & \\
\hline Blanc (2009) & & Community Capital & Stakeholder Influence & \\
\hline Cross (2009) & $\begin{array}{l}\text { Health and Safety, } \\
\text { Employment Practices }\end{array}$ & $\begin{array}{c}\text { Human Capital, } \\
\text { Community Capital }\end{array}$ & & \\
\hline $\begin{array}{l}\text { Spence and Bourlakis } \\
\qquad(2009)\end{array}$ & & Human Capital & $\begin{array}{l}\text { Information Provision, } \\
\text { Stakeholder Influence }\end{array}$ & \\
\hline $\begin{array}{l}\text { Oglethorpe and Heron } \\
\text { (2010) }\end{array}$ & & $\begin{array}{c}\text { Human Capital, } \\
\text { Community Capital }\end{array}$ & & \\
\hline $\begin{array}{l}\text { Pulina and Timpanaro } \\
\text { (2012) }\end{array}$ & Health and Safety & Human Capital & & \\
\hline Wang et al. (2013) & Health and Safety & Human Capital & $\begin{array}{l}\text { Information Provision, } \\
\text { Stakeholder Influence }\end{array}$ & \\
\hline Zhang et al (2013) & & Human Capital & & \\
\hline $\begin{array}{l}\text { Urquhart and Acott } \\
\text { (2013) }\end{array}$ & & Community Capital & Stakeholder Influence & Environmental Performance \\
\hline Manning (2013) & & Human Capital & $\begin{array}{l}\text { Information Provision, } \\
\text { Stakeholder Influence }\end{array}$ & \\
\hline $\begin{array}{l}\text { Wiese and Toporowski } \\
(2003)\end{array}$ & Health and Safety & $\begin{array}{c}\text { Human Capital, } \\
\text { Community Capital }\end{array}$ & & \\
\hline $\begin{array}{l}\text { Davenport and Low } \\
\text { (2013) }\end{array}$ & & & $\begin{array}{l}\text { Information Provision, } \\
\text { Stakeholder Influence }\end{array}$ & \\
\hline $\begin{array}{l}\text { Chen, Zhang and } \\
\text { DeLaurentis (2014) }\end{array}$ & & Human Capital & $\begin{array}{l}\text { Information Provision, } \\
\text { Stakeholder Influence }\end{array}$ & \\
\hline Bisogno (2015) & & Community Capital & Stakeholder Influence & \\
\hline Agustin et al (2015) & $\begin{array}{l}\text { Health and Safety, } \\
\text { Employment Practices, } \\
\text { Capacity Development }\end{array}$ & & $\begin{array}{l}\text { Information Provision, } \\
\text { Stakeholder Influence }\end{array}$ & \\
\hline $\begin{array}{l}\text { Shnayder, and Rijnsoever } \\
\text { Hekkert (2015) }\end{array}$ & $\begin{array}{l}\text { Health and Safety, } \\
\text { Employment Practices, } \\
\text { Capacity Development }\end{array}$ & $\begin{array}{l}\text { Human Capital } \\
\text { Productive Capital }\end{array}$ & $\begin{array}{l}\text { Information Provision, } \\
\text { Stakeholder Influence }\end{array}$ & Environmental Performance \\
\hline $\begin{array}{l}\text { Jacob-John and Veerapa } \\
\text { (2015) }\end{array}$ & & $\begin{array}{l}\text { Human Capital, } \\
\text { Community Capital }\end{array}$ & $\begin{array}{l}\text { Information Provision, } \\
\text { Stakeholder Influence }\end{array}$ & \\
\hline Carlisle (2015) & & Human Capital & $\begin{array}{l}\text { Information Provision, } \\
\text { Stakeholder Influence }\end{array}$ & \\
\hline New (2015) & $\begin{array}{l}\text { Job Stability, Health and } \\
\text { Safety, Employment } \\
\text { Practices, Capacity } \\
\text { Development }\end{array}$ & Human Capital & & \\
\hline $\begin{array}{l}\text { Tidy, Wang and Hall } \\
\text { (2016) }\end{array}$ & & & Stakeholder Influence & \\
\hline $\begin{array}{l}\text { Wilhelm Blome and } \\
\text { Wieck (2016) }\end{array}$ & $\begin{array}{l}\text { Health and Safety, } \\
\text { Employment Practices }\end{array}$ & Human Capital & Stakeholder Influence & Environmental Performance \\
\hline $\begin{array}{l}\text { Giovannucci and Potts } \\
\text { (2016) }\end{array}$ & & $\begin{array}{l}\text { Human Capital } \\
\text { Productive Capital }\end{array}$ & & $\begin{array}{c}\text { Financial } \\
\text { and Environmental } \\
\text { Performance }\end{array}$ \\
\hline Beber et al. (2016) & $\begin{array}{l}\text { Job Stability, Health and } \\
\text { Safety, Employment } \\
\text { Practices, Capacity } \\
\text { Development }\end{array}$ & $\begin{array}{l}\text { Human Capital, } \\
\text { Community Capital }\end{array}$ & $\begin{array}{l}\text { Information Provision, } \\
\text { Stakeholder Influence }\end{array}$ & Environmental Performance \\
\hline Li et al. (2016) & & Human Capital & & \\
\hline $\begin{array}{l}\text { Famiola and Adiwoso } \\
\text { (2016) }\end{array}$ & & $\begin{array}{l}\text { Human Capital, } \\
\text { Community Capital, } \\
\text { Capital Productive }\end{array}$ & & \\
\hline $\begin{array}{c}\text { Zhang, Lin and Liu } \\
(2016)\end{array}$ & & Human Capital & Information Provision & \\
\hline
\end{tabular}


INDEPENDENT JOURNAL OF MANAGEMENT \& PRODUCTION (IJM\&P)

http://Www.ijmp.jor.br

V. 10, n. 5, September-October 2019

ISSN: 2236-269X

DOI: 10.14807/ijmp.v10i5.894

Analyzing Table 2, it is possible to observe, in the majority, social sustainability indicators related to the external population (25), followed by the stakeholder participation (20), internal human resources (11) and, lastly, indicators related to the macro-social performance (6). These results already demonstrate a greater academic approach on elements that are external to the target organization, since indicators related to internal human resources are present in only 11 articles.

Among the spheres of sustainability indicators, considering the external population, it is verified that human capital was the predominant indicator, being approached in 22 articles. The frequency of approaching this indicator in the analyzed articles demonstrates the importance given to human aspects such as health, education and local development of the communities, due to the impacts of agrifood enterprises. Elkington (1997) emphasizes that aspects related to human capital should encompass broader aspects of society and the potential for wealth creation in order to contemplate health, education and skills in populations.

In the category related to stakeholder participation, most articles deal with the stakeholder influence (19) followed by the information provision (15). Thus, the authors highlight the empowerment of stakeholders and the importance of more effective positioning and relationship strategies, especially of the most fragile members in the agrifood supply chain. Another highlight in the indicators is related to the provision of information, in order to reduce the asymmetry in supply chains, as well as providing social and environmental information to different internal and external groups.

The indicators inherent in internal human resources organizations have shown to be practically aligned with issues of prevention of occupational diseases and labor safety actions, framed under the health and safety indicator.

The results related to macro-social issues obtained a lower number of approaches among the other indicators considered in this study, addressed in only 6 articles when considering aspects related to social and environmental performance. The socio-environmental performance of a macro-social analysis considers social and environmental transformations at regional and national level, being one of the reasons for the low approach in these studies, since the impacts on a larger scale are generated by enterprises with larger scale of agrifood production and extrapolate most of the articles, which are practically composed of case studies. 
INDEPENDENT JOURNAL OF MANAGEMENT \& PRODUCTION (IJM\&P)

http://Www.ijmp.jor.br

V. 10, n. 5, September-October 2019

ISSN: 2236-269X

DOI: 10.14807/ijmp.v10i5.894

The articles that compose the sample presented indicators of social sustainability that presuppose that, for its effectiveness and transition to sustainability in agrifood supply chains, it is necessary to provide cooperative or collaborative arrangements among stakeholders. Silva and Lourenzani (2011) stress that cooperative arrangements between agents of an agrifood supply chain favor alternatives for the insertion of more fragile entities into the distribution and commercialization channels, and also in the improvement of social welfare.

Based on the collective and integrative cooperation and collaboration relationships identified in the sample articles, as specified in Table 3, it is noteworthy that all articles displayed cooperative approaches as emphasized by Chen et al. (2017), the collaborative arrangements have become a concern for companies, mainly regarding the balance among environmental, social and economic issues.

Brito (2001) reinforced this statement. Among the cooperative actions identified, these were classified according to Britto (2002) and, also presented in Table 3 . In the classifications of cooperative approaches, interorganizational cooperation was predominant (25), followed by technological cooperation (21) and, finally, technical-productive cooperation (11). Therefore, there is a predominance of cooperation involving elements that influence decision-making between chain entities or the cooperative network, followed by cooperative actions related to information exchange that optimize the innovation process and, to a lesser extent, cooperating to improve operational and production efficiency among chain or network agents.

Based on the collective and integrative cooperation and collaboration relationships identified in the sample articles, as specified in Table 3, it is noteworthy that all articles displayed cooperative approaches. Among the cooperative actions identified, these were classified according to Britto (2002) and also presented in Table 3 . In the classifications of cooperative approaches, interorganizational cooperation was predominant (25), followed by technological cooperation (21) and, finally, technical-productive cooperation (11). Therefore, there is a predominance of cooperation involving elements that influence decision-making between chain entities or the cooperative network, followed by cooperative actions related to information exchange that optimize the innovation process and, to a lesser extent, cooperating to improve operational and production efficiency among chain or network agents. 
INDEPENDENT JOURNAL OF MANAGEMENT \& PRODUCTION (IJM\&P)

http://www.ijmp.jor.br

V. 10, n. 5, September-October 2019

ISSN: 2236-269X

DOI: 10.14807/ijmp.v10i5.894

Table 3: Categories of cooperative and collaborative actions.

\begin{tabular}{|c|c|c|c|c|c|}
\hline AUTHORS & $\begin{array}{l}\text { COOPERATIVE } \\
\text { ACTIONS }\end{array}$ & COLLABORATION & VERT. & HORIZ. & $\begin{array}{l}\text { COLLABORATION } \\
\text { RELATIONS }\end{array}$ \\
\hline $\begin{array}{l}\text { Manning, Baines } \\
\text { and Chadd (2006) }\end{array}$ & Interorganizational & & & & \\
\hline $\begin{array}{c}\text { Rimmington, } \\
\text { Carlton and } \\
\text { Hawkins (2006) }\end{array}$ & $\begin{array}{c}\text { Interorganizational and } \\
\text { technological }\end{array}$ & & & & Consumer/Supplier \\
\hline $\begin{array}{l}\text { Fearne, Duffy and } \\
\text { Hornibrook (2006) }\end{array}$ & Interorganizational & $\begin{array}{c}\text { Information Sharing / } \\
\text { Technological and Scientific } \\
\text { Dissemination }\end{array}$ & $\mathrm{x}$ & & Retailer / Supplier \\
\hline $\begin{array}{l}\text { Setthasakko } \\
(2007)\end{array}$ & Interorganizational & & & & \\
\hline Blanc (2009) & $\begin{array}{l}\text { Technical-productive, } \\
\text { interorganizational and } \\
\text { technological }\end{array}$ & $\begin{array}{c}\text { Information Sharing / } \\
\text { Infrastructure Sharing// } \\
\text { Technological and Scientific } \\
\text { Dissemination }\end{array}$ & & $\mathrm{x}$ & Among suppliers \\
\hline Cross (2009) & $\begin{array}{l}\text { Technical-productive, } \\
\text { interorganizational and } \\
\text { technological }\end{array}$ & & & & \\
\hline $\begin{array}{c}\text { Spence and } \\
\text { Bourlakis (2009) }\end{array}$ & $\begin{array}{l}\text { Interorganizational and } \\
\text { technological }\end{array}$ & $\begin{array}{c}\text { Information Sharing / } \\
\text { Technological and Scientific } \\
\text { Dissemination }\end{array}$ & $\mathrm{x}$ & & Retailer / Supplier \\
\hline $\begin{array}{l}\text { Oglethorpe and } \\
\text { Heron }(2010)\end{array}$ & $\begin{array}{l}\text { Technical-productive, } \\
\text { interorganizational and } \\
\text { technological }\end{array}$ & & & & \\
\hline $\begin{array}{c}\text { Pulina and } \\
\text { Timpanaro (2012) }\end{array}$ & Technical-productive & $\begin{array}{c}\text { Technological and Scientific } \\
\text { Dissemination }\end{array}$ & $\mathrm{x}$ & & $\begin{array}{l}\text { Supplier / Industry / } \\
\text { Consumer }\end{array}$ \\
\hline $\begin{array}{l}\text { Wanga et } \\
\text { al. (2013) }\end{array}$ & $\begin{array}{c}\text { Interorganizational and } \\
\text { technological }\end{array}$ & $\begin{array}{c}\text { Technological and Scientific } \\
\text { Dissemination }\end{array}$ & & $\mathrm{x}$ & Among restaurants \\
\hline $\begin{array}{l}\text { Zhang et } \\
\text { a1. (2013) }\end{array}$ & Interorganizational & Information Sharing & $\mathrm{x}$ & & Industry / Retailer \\
\hline $\begin{array}{l}\text { Urquhart and } \\
\text { Acott (2013) }\end{array}$ & $\begin{array}{c}\text { Technical-productive, } \\
\text { interorganizational and } \\
\text { technological }\end{array}$ & $\begin{array}{c}\text { Information Sharing/ } \\
\text { Infrastructure Sharing// } \\
\text { Technological and Scientific } \\
\text { Dissemination }\end{array}$ & & $\mathrm{x}$ & Among suppliers \\
\hline Manning (2013) & Interorganizational & & & & \\
\hline $\begin{array}{l}\text { Wiese and } \\
\text { Toporowski } \\
\text { (2003) }\end{array}$ & $\begin{array}{l}\text { Technical-productive, } \\
\text { interorganizational and } \\
\text { technological }\end{array}$ & & & & Retailer / Supplier \\
\hline $\begin{array}{l}\text { Davenport and } \\
\text { Low (2013) }\end{array}$ & $\begin{array}{l}\text { Technical-productive, } \\
\text { interorganizational and } \\
\text { technological }\end{array}$ & & & & \\
\hline $\begin{array}{l}\text { Chen, JunZhang } \\
\text { and DeLaurentis } \\
(2014)\end{array}$ & $\begin{array}{l}\text { Interorganizational and } \\
\text { technological }\end{array}$ & Information Sharing & $\mathrm{x}$ & & Retailer / Supplier \\
\hline Bisognoa (2015) & $\begin{array}{l}\text { Interorganizational and } \\
\text { technological }\end{array}$ & $\begin{array}{l}\text { Information Sharing / } \\
\text { Infrastructure Sharing / }\end{array}$ & & $\mathrm{x}$ & Among suppliers \\
\hline Bisognoa (2015) & $\begin{array}{l}\text { Interorganizational and } \\
\text { technological }\end{array}$ & $\begin{array}{c}\text { Information Sharing / } \\
\text { Infrastructure Sharing / } \\
\text { Technological and Scientific } \\
\text { Dissemination }\end{array}$ & & $\mathrm{x}$ & Among suppliers \\
\hline $\begin{array}{l}\text { Agustin et } \\
\text { al. }(2015)\end{array}$ & $\begin{array}{l}\text { Technical-productive, } \\
\text { interorganizational and } \\
\text { technological }\end{array}$ & $\begin{array}{c}\text { Integration of Productive } \\
\text { Processes / Information Sharing } \\
\text { / Infrastructure Sharing / } \\
\text { Technological and Scientific } \\
\text { Dissemination }\end{array}$ & $\mathrm{x}$ & $\mathrm{x}$ & $\begin{array}{l}\text { Supplier / Industry / } \\
\text { Consumer }\end{array}$ \\
\hline $\begin{array}{l}\text { Shnayder, and } \\
\text { Rijnsoever } \\
\text { Hekkert (2015) }\end{array}$ & Technological & Information Sharing & & $\mathrm{x}$ & Among industries \\
\hline $\begin{array}{l}\text { Jacob-John and } \\
\text { Veerapa (2015) }\end{array}$ & $\begin{array}{c}\text { Interorganizational and } \\
\text { technological }\end{array}$ & & & & \\
\hline Carlisle (2015) & $\begin{array}{l}\text { Technical-productive, } \\
\text { interorganizational and } \\
\text { technological }\end{array}$ & $\begin{array}{c}\text { Information Sharing / } \\
\text { Infrastructure Sharing/ } \\
\text { Technological and Scientific } \\
\text { Dissemination }\end{array}$ & & $\mathrm{x}$ & Among Suppliers \\
\hline New (2015) & Interorganizational & & & & \\
\hline $\begin{array}{l}\text { Tidy, and Wang } \\
\text { Hall (2016) }\end{array}$ & Interorganizational & & & & \\
\hline $\begin{array}{l}\text { Wilhelm Blome } \\
\text { and Wieck (2016) }\end{array}$ & $\begin{array}{c}\text { Interorganizational and } \\
\text { technological }\end{array}$ & & & & \\
\hline $\begin{array}{l}\text { Giovannucci and } \\
\text { Potts (2016) }\end{array}$ & Technological & $\begin{array}{l}\text { Information Sharing / } \\
\text { Infrastructure Sharing }\end{array}$ & $\mathrm{x}$ & & Industry / Supplier \\
\hline Beer et al. (2016) & $\begin{array}{l}\text { Technical-productive, } \\
\text { interorganizational and } \\
\text { technological }\end{array}$ & & & & \\
\hline Li et al. (2016) & $\begin{array}{c}\text { Interorganizational and } \\
\text { technological }\end{array}$ & & & & \\
\hline $\begin{array}{c}\text { Famiola and } \\
\text { Adiwoso (2016) }\end{array}$ & $\begin{array}{c}\text { Technical-productive, } \\
\text { interorganizational and } \\
\text { technological }\end{array}$ & $\begin{array}{c}\text { Technological and Scientific } \\
\text { Dissemination }\end{array}$ & $\mathrm{x}$ & & Industry / Supplier \\
\hline $\begin{array}{l}\text { Zhang, } \operatorname{Lin} \text { and } \\
\text { Liu }(2016)\end{array}$ & Technological & $\begin{array}{c}\text { Technological and Scientific } \\
\text { Dissemination }\end{array}$ & $\mathrm{x}$ & & Industry / Supplier \\
\hline
\end{tabular}


INDEPENDENT JOURNAL OF MANAGEMENT \& PRODUCTION (IJM\&P)

http://Www.ijmp.jor.br

V. 10, n. 5, September-October 2019

ISSN: 2236-269X

DOI: 10.14807/ijmp.v10i5.894

On the other hand, in collaborative actions, where an evolutionary relationship is expected and presupposes a joint implementation and shared management by common objectives within supply chains, 15 of the 29 articles collected in the sample displayed this type of integration among the members. Collaborative actions are classified according to Barrat (2004), and it is shown that in the sample there was a predominance of collaborative interactions in information sharing (11) and technological and scientific dissemination (11). The results show that the collaborative arrangements are evidenced in researches that investigate agrifood supply chains of organizations where this interaction predominates to overcome information flow bottlenecks and promote technological cooperation between entities.

The collaborative arrangements for infrastructure sharing and integration of productive process were presented only in 6 and 1 articles of the sample, respectively.

Observing the analysis of these interactions, it can be seen that collaborative arrangements are scarce in articles when they refer to the infrastructure sharing and the production process, which shows very distinct characteristics of business among the members in the agrifood supply chain, since rural producers, retailers, wholesalers and branches of industry present a very distinct configuration of activity and economic and social development. However, because they are chains with a high degree of uncertainty and price volatility, overcoming bottlenecks related to information asymmetry and the incorporation of technological processes, especially for farmers, makes the research more compelling.

When verifying the types of collaborative interactions between vertical and horizontal, the latter was presented in 7 articles and the former, in 9. Considering the vertical collaborative interactions, the occurrences were: industry / supplier (3), retailer / supplier (3), supplier / industry / consumer (2) and industry / retailer (1). As for horizontal interactions, there was predominance of interactions between suppliers (4), and in the others, only 1 article.

The vertical collaborative relationships identified displayed a close relationship in the integrative relations with suppliers, which, in this case, are presented in most approaches with integrations between rural producers. The same happens in the horizontal interactions, with higher frequency of rural producers, where the formalization of groups, associativism or cooperativism, shaped the collaborative 
arrangements. This information demonstrates that the authors' approaches to raise issues that involve relationships with farmers becomes necessary, since they are seen as the most sensitive and weakened link compared to other entities, hence the investigation of collaborative interactions next to partners and suppliers of the same level, with a view to forming collective arrangements to access markets.

The number of articles in the sample related to the state-of-the-art of social sustainability in the agrifood supply chain in the last 10 years shows a growing tendency during the period considered that began in 2006. Figure 1 shows the number of articles per year in the sample.

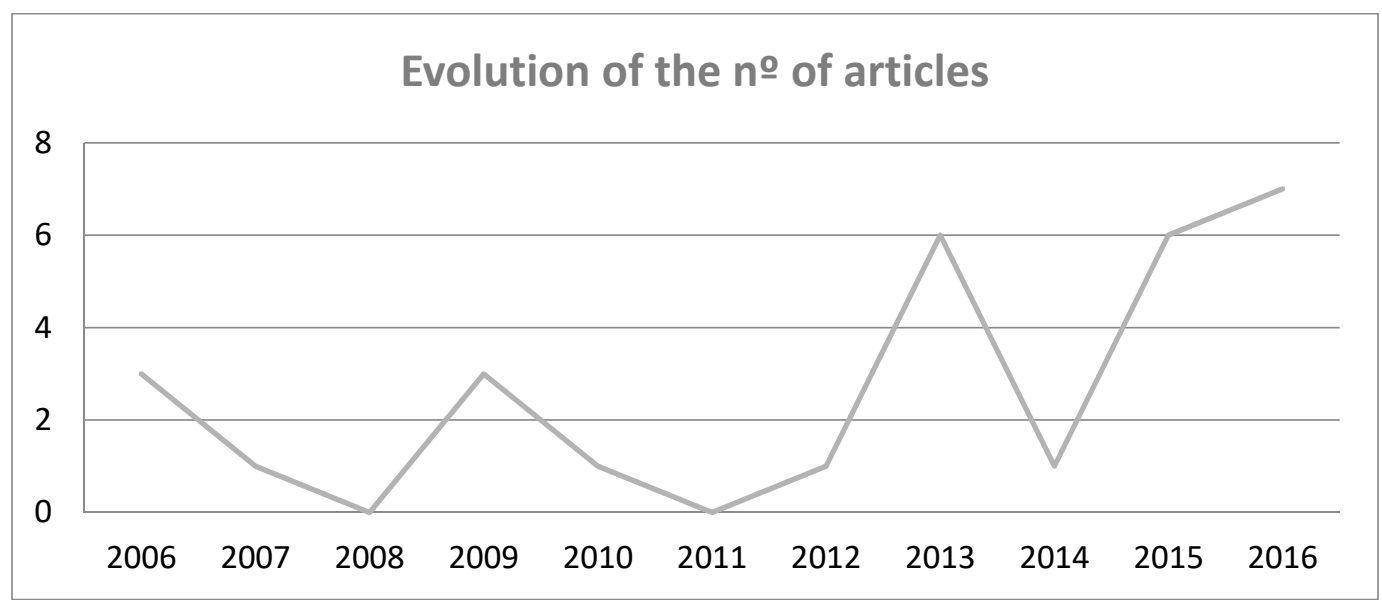

Figure 1: Number of studies per year - period from 2006 to 2016.

The Figure 1 displays an increase in the number of studies elaborated, whose peak occurs in 2016, the year in which 7 studies were produced so far, since the year has not yet finished. The trend line drawn shows the increase in studies related to social sustainability in the agrifood supply chain. Thus, more studies published in subsequent years are expected.

Despite of the research nature, $2.72 \%$ of the sample adopted the qualitative approach for the investigation and only $28 \%$ the qualitative-quantitative. No article with predominantly quantitative research was observed. The nature of research focused on qualitative studies, given that a large part of the research designs has been turned to case studies, designs that contain characteristics of research aimed at deepening and understanding phenomena in detail.

Considering the predominant research designs proposed, 3 categories were identified in the extracted sample: case study; exploratory and descriptive; and literature review. The predominant designs that were most used by the authors were 
INDEPENDENT JOURNAL OF MANAGEMENT \& PRODUCTION (IJM\&P)

http://Www.ijmp.jor.br

V. 10, n. 5, September-October 2019

ISSN: 2236-269X

DOI: 10.14807/ijmp.v10i5.894

the case studies (86\%), which shows that this type of design has an alignment close to the qualitative researches computed in high percentage in the research nature.

Exploratory and descriptive articles and those produced by literature review were designs used by only 2 articles. The results show that most of the authors focused on deepening the indicators, actions, phenomena and processes related to social sustainability of the chain or specific and chosen supply networks for research. It should be noted that no studies that considered survey-type or essentially experimental designs were detected.

\section{CONCLUDING REMARKS}

This paper has identified, in the international literature, the state-of-the-art of research on social sustainability in agrifood supply chains. Considering the general analysis of the selected studies, there is a large predominance of papers addressing social indicators related to actions with external populations that are affected, influenced or impacted in some way by members or processes. The most important aspects of the external population were those inherent to the human capital, in factors such as health, education and development of communities that supply raw materials. Another important sustainability indicator refers to stakeholder participation, where it was addressed the empowerment of more fragile entities in the chain and overcoming market access bottlenecks with reduced information asymmetry to increase efficiency gains for productive chains.

The sustainable management of a supply chain foresees joint actions to provide responsibilities among members as a prerequisite for their development and advantages (CAO; ZHANG, 2011). The sustainability indicators identified in this paper presuppose collective arrangements that were achieved cooperatively, when working together to achieve a common goal (GUARNIERI, 2014).

Considering the results of the analyses made, the studies analyzed predominantly expose interorganizational and technological cooperation. This predominance demonstrates that aspects related to the reestablishment of trust between the entities that participate in the agrifood chains in order to provide information exchange and improvement of production planning, especially for suppliers of raw materials, is a fundamental condition for the social sustainability of the chains. The analysis of the papers also shows that cooperative technological 
aspects are fundamental to reduce the uncertainties inherent in the agrifood supply chain.

Yet in those articles where integrative aspects were identified, configured as collaborative, in a joint and interactive action of the chain members, the sample presented a smaller proportion in relation to the cooperative arrangements extracted. This result indicates that the collaborative relationships require a more complex analysis and appear to a lesser extent in case-study studies of agrifood chains, since, being a more complex arrangement, it presupposes a lower frequency of detection. In the collaborative approaches detected, predominant is the sample of vertical relations involving, mostly, suppliers, which indicates research universes aimed at rural producers, usually the most fragile link in a supply chain containing large retailers and wholesalers.

Due to the evolution of the number of studies each year, it is observed that the increase in research related to social sustainability in the agrifood supply chain is increasing, although it is still low. The result reflects the greater attention to the theme in recent years, since social issues are beginning to emerge for a sustainable management in the supply chain, after a greater focus on the aspects related to the financial and environmental dimensions.

The present paper indicates gaps in the literature for the future development of researches, as such as: (a) indicators of social sustainability in macro-social issues that investigate aspects of regional or national impact regarding the population gains obtained in the development of agrifood supply chains; (b) collaborative actions and arrangements related to the infrastructure sharing and integration of productive processes between entities of the agrifood supply chain; (c) vertical collaboration between food industries and consumers; and (d) horizontal collaboration among food industry, retailers and consumers.

As limitations, the research was restricted to bibliographic queries in some academic portals, and the results that demonstrate the state-of-the-art is restricted to the sample analyzed. Because it is an exploratory and descriptive study, the results, as well as the sample analyzed, are not statistical, therefore, it is inappropriate to extrapolate for analyses at populational levels. In addition, the articles that are the object of this analysis are restricted to the social dimension in the agrifood supply 
INDEPENDENT JOURNAL OF MANAGEMENT \& PRODUCTION (IJM\&P)

http://Www.ijmp.jor.br

V. 10, n. 5, September-October 2019

ISSN: 2236-269X

DOI: 10.14807/ijmp.v10i5.894

chains, not extracting indicators related to the environmental or economic dimensions, although these are present in numerous articles of the sample.

Finally, the study contributes to identify gaps related to the proposed theme, as well as demonstrates the state-of-the-art of the researches on social sustainability in agrifood supply chains, considering the sample filtering process. Thus, from this scenario, new fields of research are indicated, given the gaps pointed out by this study, which can be useful for practitioners and academics interested in this field of knowledge.

\section{REFERENCES}

AHMED, A.; MCQUAID, R. W. (2005) Entrepreneurship, management, and sustainable development. World Review of Entrepreneurship, Management, and Sustainable Development, v. 1, n. 1, p. 6-30.

BARDIN L. (1977) L'Analyse de contenu. Editora: Presses Universitaires de France.

BARRATT, M. (2004) Understanding the meaning of collaboration in the supply chain, Supply Chain Management: An International Journal, v. 9, n. 1, p. 30-42.

BATT, P. F. (2003) Building trust between growers and market agents. Supply Chain Management: an international journal, v. 8, n. 1.

BEBER, C. et al. (2016) Sustainability of processed foods supply chain: Social, economic and territorial performance. In: BIO Web of Conferences. EDP Sciences, p. 3009.

BISOGNO, M. (2016) Corporate social responsibility and supply chains: contribution to the sustainability of well-being. Agriculture and agricultural science Procedia, v. 8, p. 441-448.

BLANC, J. (2009) Family farmers and major retail chains in the Brazilian organic sector: Assessing new development pathways. A case study in a peri-urban district of São Paulo. Journal of Rural Studies, v. 25, n. 3, p. 322-332.

BRITO, C. M. (2001) Towards an institutional theory of the dynamics of industrial network. Journal of Business \& Industrial Marketing, v. 16, n. 3. p. 150-166.

BRITTO, J. (2002) Cooperação interindustrial e redes de empresas. In: KUPFER, D.; HASENCLEVER, L. Economia industrial: fundamentos teóricos e práticas no Brasil. Rio de Janeiro: Campus, p. 688.

CAO, M.; ZHANG, Q. (2011) Supply chain collaboration: impact on collaborative advantage and firm performance, Journal of Operations Management, v. 29, n. 3, p. 163-180.

CARLISLE, L. (2015) Audits and agrarianism: The moral economy of an alternative food network. Elementa: Science of the Anthropocene, v. 3.

CARTER, C. R.; ROGERS, D. S. (2008) A framework of sustain able supply chain management: moving toward new theory. International Journal of Physical Distribution \& Logistics Management, v. 38, n. 5, p. 360-387. 
CHEN, C.; ZHANG, J.; DELAURENTIS, T. (2014) Quality control in food supply chain management: An analytical model and case study of the adulterated milk incident in China. International Journal of Production Economics, v. 152, p. 188-199.

CHEN, L. et al. (2017) Supply chain collaboration for sustainability: A literature review and future research agenda. International Journal of Production Economics, v. 194, December 2017, p. 73-87.

COOK D. J.; MULROW C. D.; HAYNES R. B. (1997) Systematic reviews: synthesis of best evidence for clinical, decisions. Ann Intern Med., v. 126, n. 5, p. 376-8.

CRONIN, P.; RYAN, F.; COUGHLAN, M. (2008) Undertaking a literature review: a step - by - step approach. British Journal of Nursing, v. 17, n. 1, p. 38-43.

CROSS, P. et al. (2009) Does farm worker health vary between localised and globalised food supply systems? Environment international, v. 35, n. 7, p. 10041014.

DANIA, W. A. P.; XING, K.; AMER, Y. (2016) Collaboration and sustainable agrifood suply chain: a literature review, Matec Web of Conferences, v. 58.

DAVENPORT, E.; LOW, W. (2013) From trust to compliance: accountability in the fair trade movement. Social Enterprise Journal, v. 9, n. 1, p. 88-101.

DYLLICK, T.; HOCKERTS, K. (2002) Beyond the business case for corporate sustainability. Business Strategy and the Environment, n. 11, p. 130-141.

ELKINGTON, J. (1997) Cannibals with forks - Triple bottom line of 21st century business. Stoney Creek, CT: New Society Publishers.

FAMIOLA, M.; ADIWOSO, S. A. (2016) Corporate social responsibility diffusion by multinational subsidiaries in Indonesia: organisational dynamic and institutional effect. Social Responsibility Journal, v. 12, n. 1, p. 117-129.

FEARNE, A.; DUFFY, R.; HORNIBROOK, S. (2005) Justice in UK supermarket buyersupplier relationships: an empirical analysis. International Journal of Retail \& Distribution Management, v. 33, n. 8, p. 570-582.

FOLADORI, G. (2002) Avanços e limites da sustentabilidade social. Revista Paranaense de Desenvolvimento, Curitiba, n. 102, p.103-113, jan./jun.

FUKUYAMA, F. (1995) Trust: The social virtues and the creation of prosperity. Hamish Hamilton.

GIOVANNUCCI, D.; POTTS, J. (2015) Ethical Commodities: Issues in Their Production, Credibility, and Trade.

GREEN, K.; MORTON, B.; NEW, S. (1998) Green Purchasing and Supply Policies: Do they improve company's environmental performance? Supply Chain Management: An International Journal, v. 3, n. 2, p. 89-95.

GUARNIERI, P. (2014) Decision making regarding information sharing in collaborative relationships under an MCDA perspective. International. Journal of Management and Decision Making, v. 13, n. 1, 2014.

GUARNIERI, P.; TROJAN, F. (2019) Decision making on supplier selection based on social, ethical, and environmental criteria: A study in the textile industry. Resources, Conservation and Recycling, v. 141, p. 347-361. 
HALL, J.; MATOS, S. (2010) Incorporating impoverished communities in sustainable supply chains, International Journal of Physical Distribution \& Logistics Management, v. 40, n. 1/2, p.124-147.

HOLLIDAY, C. O.; SCHMIDHEINY, S.; WATTS, P. (2002) Walking the Talk: the usiness Case for Sustainable Development. Greenleaf: Sheffield. International Institute for Sustainable Development (IISD), Deloitte \& Touche, World Business Council for Sustainable Development (WBCSD).

JACOB-JOHN, J.; VEERAPA, N. (2015) Stakeholder perception of the ethics of an industry: The case of organic food in South India. European Journal of Sustainable Development, v. 4, n. 3, p. 151-160.

JENKINS, R. (2011) Industry and Environment in Latin American. Routledge Research Global Environmental Changes Series. England: Routledge.

KLEINDORFER, P. R.; SINGHAL, K.; VAN WASSENHOVE, L. N. (2005) Sustainable Operations Management. Production and Operations Management, v. 14, n. 4, p. 482-492.

LABUSCHAGNE C.; BRENT, A. C. (2005) Sustainable project life cycle management: the need to integrate life cycles in the manufacturing sector. International Journal of Project Management, v. 23, n. 2, p. 159-168.

LABUSCHAGNE, C.; BRENT, A. C.; ERCK, R. P. G. (2005) Van Assessing the sustainability performances of industries. Journal of Cleaner Production, p. 1-13.

LAMBERT, D. M.; COOPER, M. C.; PAGH, J. D. (1998) Supply chain management: implementation issues and research opportunities, The International Journal of Logistic Management, v. 30, n. 2, p.1-19.

LI, Y. et al. (2015) Influencing factors of knowledge dissemination in rural areas in China. Nankai Business Review International, v. 6, n. 2, p. 128-155.

MALONI, M. J.; BROWN, M. E. (2006) Corporate social responsibility in the supply chain: an application in the food industry, Journal of business ethics, v. 68, n. 1, p. 35-52.

MANNING, L. (2013) Corporate and consumer social responsibility in the food supply chain. British Food Journal, v. 115, n. 1, p. 9-29.

MANNING, L.; BAINES, R. N.; CHADD, S. A. T. (2006) Ethical modelling of the food supply chain. British Food Journal, v. 108, n. 5, p. 358-370.

NEW, S. J. (2015) Modern slavery and the supply chain: the limits of corporate social responsibility? Supply Chain Management: An International Journal, v. 20, n. 6, p. 697-707.

OGLETHORPE, D.; HERON, G. (2010) Sensible operational choices for the climate change agenda. The International Journal of Logistics Management, v. 21, n. 3, p. 538-557.

ORDONEZ, J. (2000) 'McDonald's Hen-Care Guidelines Lead Egg Producers to Warn of Higher Prices', Wall Street Journal, Aug 24, B16.

PAGELL, M; WU, Z. (2009) Building a more complete theory of sustainable supply chain management using case studies of 10 exemplars. Journal of Supply Chain Management, v. 45, n. 2, p. 37-56, Abr. 
PULINA, P.; TIMPANARO, G.. (2012) Ethics, sustainability and logistics in agricultural and agri-food economics research. Italian Journal of Agronomy, v. 7, n. 3, p. 33.

RIMMINGTON, M.; CARLTON SMITH, J.; HAWKINS, R. (2006) Corporate social responsibility and sustainable food procurement. British Food Journal, v. 108, n. 10, p. 824-837, 2006.

SARKIS, J.; HELMS, M. M.; HERVANI, A. A. (2010) Reverse logistics and social sustainability. Corporate Social Responsibility and Environmental Management, n. 17, p. 337-354.

SETTHASAKKO, W. (2007) Determinants of corporate sustainability: Thai frozen seafood processors. British food journal, v. 109, n. 2, p. 155-168.

SEURING, S.; SARKIS, J.; MULLER, M.; RAO, P. (2008) Sustainability and supply chain management - an introduction to the special issue. Elsevier: Journal of Cleaner Production, v. 16, n.15, p. 1545-1551.

SHNAYDER, L.; VAN RIJNSOEVER, F. J.; HEKKERT, M. P. (2015) Putting your money where your mouth is: Why sustainability reporting based on the triple bottom line can be misleading. PloS one, v. 10, n. 3, p. e0119036.

SILVA, A. L.; LOURENZANI, A. E. B. S. (2011) Modelo sistêmico de ocorrência de ações coletivas: um estudo multicaso na comercialização de frutas, legumes e verduras. Gestão \&. Produção, São Carlos, v. 18, n. 1, p. 159-174.

SPENCE, L.; BOURLAKIS, M. (2009) The evolution from corporate social responsibility to supply chain responsibility: the case of Waitrose. Supply Chain Management: An International Journal, v. 14, n. 4, p. 291-302.

SRIVASTAVA, S. K. (2007) Green Supply Chain Management: A State-of-the-Art Literature Review. International Journal of Management Reviews, v. 9, n. 1, p. 5380. http://dx.doi.org/10.1111/j.1468-2370.2007.00202.x

TERRY, J. (1983) Campbell. Soup in Hot Water with Organized Labor., Business and Society Review, v. 88, n. 46, p. 37-41.

TIDY, M.; WANG, X.; HALL, M. (2016) The role of Supplier Relationship Management in reducing Greenhouse Gas emissions from food supply chains: supplier engagement in the UK supermarket sector. Journal of Cleaner Production, v. 112, p. 3294-3305.

URQUHART, J.; ACOTT, T. G. (2013) Re-connecting and embedding food in place: Rural development and inshore fisheries in Cornwall, UK. Journal of Rural Studies, v. 32 , p. 357-364.

VALIDI, S.; BHATTACHARYA, A.; BYRNE, P. J. (2014) A case analysis of a sustainable food supply chain distribution system-A multi-objective approach', International Journal of Production Economics, v.152, p. 71-87.

VIEIRA, J.; YOSHIZAKI, H.; HO, L. (2009) Collaboration intensity in the Brazilian supermarket retail chain. Supply Chain Management: An International Journal, v. 14, n. 1, p. 11-21.

VIFELL, A. C.; SONERYD, L. (2012) Organizing matters: how 'the social dimension' gets lost in sustainability projects. Sustainable Development, n. 20, p. 18-27.

VISSER, W.; SUNTER, C. (2002) Beyond Reasonable Greed: Why Sustainable Business is a Much Better Idea. Human and Rousseau, Tafelberg: Cape Town. 
WANG, Y.-F. et al. (2013) Developing green management standards for restaurants: An application of green supply chain management. International Journal of Hospitality Management, v. 34, p. 263-273.

WEBSTER, J.; WATSON, R. T. (2002) Analyzing the Past to Prepare for the Future: Writing a Literature Review. MIS Quarterly, v. 26, n. 2, p. xiii-xxiii.

WIESE, A.; TOPOROWSKI, W. (2013) CSR failures in food supply chains-an agency perspective. British Food Journal, v. 115, n. 1, p. 92-107.

WILHELM, M. et al. (2016) Implementing sustainability in multi-tier supply chains: Strategies and contingencies in managing sub-suppliers. International Journal of Production Economics, v. 182, p. 196-212.

ZHANG, W. et al. (2014) On the impact of advertising initiatives in supply chains. European Journal of Operational Research, v. 234, n. 1, p. 99-107.

ZHANG, B.; LIN, J.; LIU, R. (2016) Factors affecting the food firm's intention to control quality safety in China: The moderating effect of government regulation. Chinese Management Studies, v. 10, n. 2, p. 256-271. 